（大阪大学工学部応用化学教室：大阪市都島区）（昭和 28 年 7 月 22 日受理）

\title{
（32）レプリン酸及びその誘導体に関する研究（第 2 報）
}

\author{
接触的水素添加による $\gamma$-バレロラクトンの製造及び還元
}

林泉・根 来 英二・八 浜 義 和

\section{1. 緒 殕}

レブリン酸（I）が今後わが国で注目すべき化学工業原料であ ることは第 1 報1 で既にのべた。レブリン酸を還元して得られる

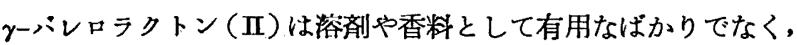
種々の合成の中間体としてる重要である。本報ではレブリン酸の 接触的水素添加による $\gamma$-バレロラクトンの製造と，それを更に 水素添加して 1,4-ペンタンジオール（III）或は $\alpha$-メチルテトラ ヒドロフラン(IV)を得る実験について報告する。これら両者す共 に大きい利用価值を有し，例えば 1,4-ペンタンジオールからピ ペリレンを得んとする研究については八浜, 井本の報告2) わある

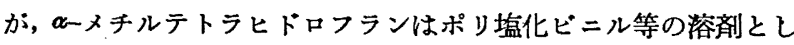
てすぐれているので, 今回は特にその生成に注目して研究した。

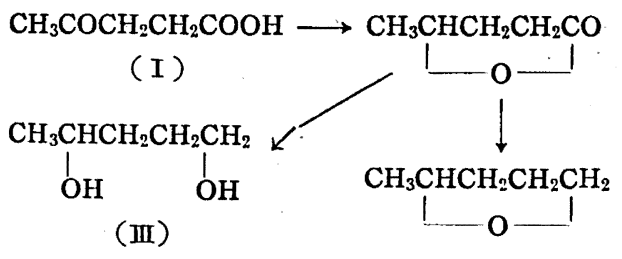

\section{2. $\gamma$-パレロラクトンの赀造}

レブリン酸から $\gamma$-パレロラクトンの製造については既に多く の方法が発表されているが3゙ー7), 工業的に最も間題となるのは水 絜添加法と思われる。ここでは主としてラネーニッヶル触媒を用 いる方法について研究した。

実驗の方法 反底䒾置には振盪式オートクレーブを使用し，原 料レブリン酸は第 1 報と同様のもの，触媒のラネーニッケルは $60^{\circ} \mathrm{C}$ で展開したもの Adkins の著書記載の方法9)によるものを使用した。反纫生成物 は一般に触媒を淐別後隇圧下に精溜して目的物 (沸点範囲 $3^{\circ} \mathrm{C}$ 程 庋のすの）を得たが，レブリン酸のソーダ㙁水溶液を水素添加し

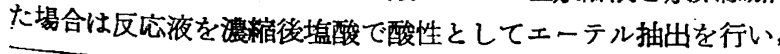

1) 八浜, 林, 工化 54, 695 (1951).

2) 八浜, 井本, 工化 45,40 (1942).

3) R. Fittig, L. Wolff, Ann. 208, 168 (1881).

4) P. Sabatier, A. Mailhe, Ann. chim. et phys. [8] 16 77 (1909).

5) K. Packendorff, Ber. 67, 905 (1934).

6) A.M. Berkenheim, T.F. Dakowa, Chem. Z. 1940, I, 853.

7) R. V. Christian, H. O. Brown, R. M. Hixon, J. Am. Chem. Soc. 69, 196 (1947).

8) 合成法集成 2,3 (1949).

9) H. Adkins, "Reactions of Hydrogen with Organic Compounds over Copper-Chromium Oxide and Nickel Catalysts" p. 13 (1937).
抽出物を蒸溜に附した。

実験の結果及び考察 実験結果の代表的なものを第 1 表に示し た。得られた $\gamma$-バレロラクトンの性状は次の通りである。沸点 $88^{\circ} \mathrm{C} / 10 \mathrm{mmHg}, d_{4}^{20} 1.0514, n_{\mathrm{D}}^{20} 1.4330$ 。

レブリン酸は溶剤を使用しなくてあ反応温度 $170 \sim 190^{\circ} \mathrm{C}$, 水 害初压 40 気圧以上ならば比較的容易に $\gamma$-バレロラクトンを与 えるが，触媒量の少い場合は長時間反応させても未反応物が残る ことが多い。ところがメタノール或はェタノールを溶刘に用いる と, 反応が円滑に進行し好収量に得られることが判つた（第 1 表 No. 3，9〜11)。水を添加した場合. (No. 8) 収量の低いことを あわせ考え，これはレブリン酸の酸性とラクトンの生成が脱水反 応であることに関連するすのと思われる。

元来ラネーニッケル触媒は中性又はアルカリ性の方が酸性に拉 けるよりも活性が大きいと考它られるので, レブリン酸に当量の 茫性ソーダを加光水溶液で反応を行わせたところ，予想通り低温 且つ低圧で反応が進行した (No. 12 以下)。この場合の生成物は

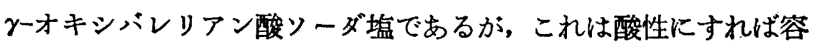
易にラクトンになる。これらの実験で収率が $90 \%$ 前後にとまつ ているのは主として分離操作上の損失で, 還元反応は完全に進行 していることが認められた。

佾この際ラネーニッケル触媒展開後の水洗は全く不要であり, 更に合金のままで使用することも出来る。即ち，No．16，17 の 実験ではレブリン酸の当量よりも過鄱の苛性ソーダを用い, ラネ ーニッケル合金は予め展開することなくそのままオートクレーブ 中に加え，直ちに蓋をしめて水素を充填したところ，同様に檽め て容易に水素が吸収された。アルカリ塩の水溶液を水素添加する 方法は装置に耐酸性の材料を要しない点でも有利であると考えら れる。

\section{3. $\gamma$-パレロラクトンの水粪添加}

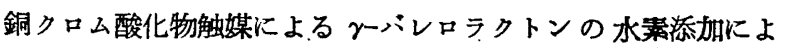
つて，1,4-ベンタンジオールを製造することについては既に数個

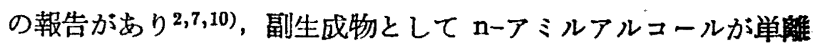
されているが，ラネーニッケル触媒を用いた実験はAdkins 等11) が $200^{\circ} \mathrm{C}$ で行い, 収率 $17 \%$ で 得たことをのべているほかは見当らない。ここではこれら両触媒 について, 特に 溶戍を用いない反応を行つた。

実験の方法 装置及び触媒は上述の通りであるが,特に

10) K. Folkers, H. Adkins, J. Am. Chem. Soc. 54, 1145 (1932).

11) H. Adkins, "Reactions of Hydrogen with Organic Compounds over Copper-Chromium Oxide and Nickel Catalysts" p. 77 (1937). 


\begin{tabular}{|c|c|c|c|c|c|c|c|c|c|c|}
\hline No. & $\begin{array}{c}\text { レブリン酸 } \\
(\mathrm{M})\end{array}$ & $\underset{(\mathrm{g})}{\mathrm{NaOH}}$ & (cc) & 剂 & 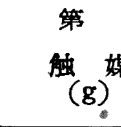 & & $\begin{array}{c}\text { 表 } \\
\text { 水素初压 } \\
\left(\mathrm{kg} / \mathrm{cm}^{2}\right)\end{array}$ & $\begin{array}{l}\text { 反底温度 } \\
\left({ }^{\circ} \mathrm{C}\right)\end{array}$ & $\begin{array}{c}\text { 反庶時間 } \\
\text { (hr) }\end{array}$ & $\begin{array}{c}\text { シレロラクトン } \\
\text { (収率\%) }\end{array}$ \\
\hline 1 & 2 & - & - & & $\mathrm{CuCr}$ & 10 & 100 & $160 \sim 200$ & 5.0 & 81 \\
\hline 2 & $" \prime$ & - & & & $" \prime$ & 20 & 80 & $" \prime$ & 3.5 & 82 \\
\hline 3 & 1 & - & EtOH & 150 & $" \prime$ & 10 & 75 & $160 \sim 190$ & 2.5 & 84 \\
\hline 4 & 2 & - & & & $\mathrm{Ni}(\mathrm{R})$ & 5 & 60 & $150 \sim 190$ & 6.0 & 67 \\
\hline 5 & "I & - & & & 11 & 10 & 85 & "I & 3.2 & 81 \\
\hline 6 & $" \prime$ & - & & & " & 20 & 40 & $160 \sim 200$ & 2.5 & 91 \\
\hline 7 & 1 & - & & & $" \prime$ & 10 & 63 & $160 \sim 190$ & 2.2 & 89 \\
\hline 8 & "I & - & $\mathrm{H}_{2} \mathrm{O}$ & 200 & $" \prime$ & $\prime \prime$ & 50 & $180 \sim 200$ & 4.0 & 10 \\
\hline 9 & $\prime \prime$ & - & EtOH & $" \prime$ & "I & $" 1$ & 60 & $160 \sim 180$ & 2.3 & 94 \\
\hline 10 & 2 & - & "I & $" \prime$ & $" \prime$ & "I & 81 & $" \prime$ & 2.0 & 95 \\
\hline 11 & $" \prime$ & - & $\mathrm{MeOH}$ & 11 & "I & $" 1$ & 54 & "I & 3.0 & 91 \\
\hline 12 & 1 & 40 & $\mathrm{H}_{2} \mathrm{O}$ & 50 & " & 5 & 68 & $80 \sim 90$ & 2.3 & 96 \\
\hline 13 & $" \prime$ & "I & "I & 100 & " & .11 & 45 & $80 \sim 110$ & 1.8 & . 92 \\
\hline 14 & "I & 44 & $" 1$ & 200 & $"$ & 10 & 38 & $80 \sim 100$ & 2.2 & 87 \\
\hline 15 & 2 & 80 & "I & $" \prime$ & "I & "I & 50 & $" \prime$ & 3.2 & 90 \\
\hline 16 & $1 "$ & 100 & "I & 350 & $\begin{array}{l}\mathrm{Ni}(\mathrm{R}) \\
\text { 合金 }\end{array}$ & 20 & 95 & $30 \sim 50$ & 3.0 & 88 \\
\hline 17 & $" \prime$ & $\prime \prime$ & " & 200 & $" \prime$ & 10 & 51 & " & "I & 89 \\
\hline
\end{tabular}

第 2 表

\begin{tabular}{|c|c|c|c|c|c|c|c|c|}
\hline No. & $\begin{array}{c}\text { ハレロラクトン } \\
(\mathrm{M})\end{array}$ & 触 $(\mathrm{g})$ & 媒 & $\begin{array}{l}\text { 永素初压 } \\
\left(\mathrm{kg} / \mathrm{cm}^{2}\right)\end{array}$ & $\begin{array}{c}\text { 反応温度 } \\
\left({ }^{\circ} \mathrm{C}\right)\end{array}$ & $\begin{array}{c}\text { 反底時間 } \\
\text { (hr) }\end{array}$ & $\begin{array}{c}\alpha \text { ーメチルテトラヒ } \\
\text { ドフラン }(\%)\end{array}$ & 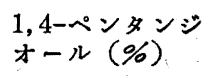 \\
\hline 1 & $2 / 3$ & $\mathrm{CuCr}$ & 10 & 65 & $200 \sim 240$ & 4 & 14 & 24 \\
\hline 2 & 1 & $" \prime$ & 20 & 73 & " & 4.5 & 17 & 50 \\
\hline 3 & $" 1$ & " & $" \prime$ & 150 & "I & 3 & 4 & 75 \\
\hline 4 & 11 & $" \prime$ & 10 & 72 & $250 \sim 270$ & "I & 28 & 32 \\
\hline 5 & $\prime \prime$ & $" 1$ & $" \prime$ & 50 & $" \prime$ & " & 33 & 30 \\
\hline 6 & $\prime \prime$ & $\mathrm{Ni}(\mathrm{R})$ & $\prime \prime$ & 98 & $200 \sim 210$ & 2.5 & 25 & - \\
\hline 7 & $" \prime$ & $" \prime$ & $" \prime$ & 75 & $230 \sim 250$ & 3 & 40 & : \\
\hline & トー゚ンタンジオー & & & & . & & & \\
\hline 8 & $1 / 2$ & $\mathrm{CuCr}$ & 5 & 53 & $250 \sim 270$ & 2.5 & 35 & 30 \\
\hline
\end{tabular}

ルテトラヒドロフランの揮発性が大きいので，反応後の液から触 媒を濾別することなく常压蒸溜を行つて $100^{\circ} \mathrm{C}$ までの溜分をと り，それを無水艺硝で脱水後精溜に附して，沸点 $75 \sim 85^{\circ} \mathrm{C}$ の溜 分を ローメチルテトラヒドロフランとして収量を求めた。次にこ の両方の蒸溜残渣を合一して触媒を演別し, 脱水後常圧及び減圧 下に精溜を行つて，1４-ペンダンジオールを分離したが，これよ りも低沸点の部分には未反忘;の $\boldsymbol{\gamma}$-バレロラクトン以外に, アミ ルアルコール，バレリアン酸その他の副生成物の存在する可能性 が考えられたので，次の如き処理を行つた。

先ずこの溜分を少量の水と层つて $\boldsymbol{\gamma}$-バレロラクトン（改び 1 , 4-ペンタンジオール）を可及的に除く。残りをエーテルでうすめ た後，重炭酸ソーダ水溶液で酸性分を抽出し，抽出液は酸性にし て再びェーテルで抽出する。かくして得た中性分及び酸性分のエ ーテル溶液は何れす無水芒硝で乾燥，エーテルを溜去後，常圧で 蒸溜し各溜分の物理恒数を測定すると共に，酸は中和価，エステ ルは踰化価を湘定し, 又酸はアニリッドを作り，アルコールは酸

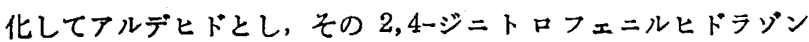
を作ることにより2)それぞれ確認した。

実験の結果 第 2 表に代表的な反底条件と ドロフラン及る゙ 1,4-ペンタンジオールの収量を示した。これら
の性状は次の如くである。

๙ーメチルテトラヒドロフラン：沸点 $78 \sim 79^{\circ} \mathrm{C}, d_{4}^{20} 0.858$, $n_{\mathrm{D}}^{20} 1.408$ 。 1,4 -ペンタンジオール：沸点 $117 \sim 118^{\circ} \mathrm{C} / 9 \mathrm{mmHg}$, $d_{4}^{25} 0.9872, n_{\mathrm{D}}^{25} 1.4424$ 。

次に副生成物についての検索の結果をのべる。

実験 No. 4 (銅ク口_酸化物触媒)：中間溜分 $20 \mathrm{~g}$ を得て上 記の如くして $\boldsymbol{\gamma}$-バレロラクトン除去後中性分と酸性分とに分離 したが，酸性分は殆ど得られなかつた。中性分のエーテル溜去後 の残渣を蒸溜して沸点 $132 \sim 138^{\circ} \mathrm{C}$ の溜分 $3.5 \mathrm{~g}$ を得た。 $d_{4}^{25}$ $0.825 ， n_{\mathrm{D}}^{25} 1.4052$ 。これをさきに行われた方法2)により $\mathrm{n}$ ○隹 レルアルデヒド-2,4-ジニトロフェニルヒドラジン（融点 98〜 $\left.99^{\circ} \mathrm{C}\right)$ に導き, 混骶により確かめ, n一アミルアルュールの生成を 確認した。

央験 No. 7 (ラネーニッケル触媒) : $\boldsymbol{a}$-メチルテトラヒドロフ ラン溜去後の反応液を水と振り, 水に䧼溶の部分を上記の如くし て中性分と酸性分とにわけた。中性分を蒸溜したところアミルア ルコールに相当する溜分は得られず，沸点 $185 \sim 195^{\circ} \mathrm{C}$ の溜分 2 $\mathrm{g}$ が得られた。 $d_{4}^{25} 0.895, n_{\mathrm{D}}^{25} 1.4155$ 。恒数, 臭気等より nーハ レリアン酸の $\mathrm{n}$-(恐らく) アミルエステルと考えられ, 路化価を 測定し比較的近い值を得ているが，そ机上の確認は行つていな 
い。铪化価 360 (計算值 325.9)。次に酸性分からは沸点 184〜 ・ $188^{\circ} \mathrm{C}$ の溜分 $3.1 \mathrm{~g}$ を得た。 $d_{4}^{25} 0.935, n_{\mathrm{D}}^{25} 1.4065$ ，中和価 540 $\left(\mathrm{C}_{4} \mathrm{H}_{\mathrm{j}} \mathrm{COOH}\right.$ として計算值 549.6)。この溜分はチオニルクロラ イドで塩素化後アニリンを反応させてアニリッドを作り（アルコ ールから再結晶して融点 $62^{\circ} \mathrm{C}$ ), 混融陚験を行つて, nーバレリア ン酸であることを確認した。エステルを形成した分を合せて $\mathrm{n}$ ハンリアン酸の理論収率 $4.3 \%$ である。合最初の水尿を蒸溜し た結果は $\boldsymbol{\gamma}$-バレロラクトンが回収されたのみで，1,4-ペンタン ジオールは単離されなかつた。

実験結果の考䩉 銅クロム酸化物触媒による ンの水素添加については從来から比較的よく研究され, 副生成物 としてnーアミルアルコールの生成する事 す既に認められている が, $\boldsymbol{\alpha}$-メチルテトラヒドロフランの生成は最近 Christian7) 等が 定性的に見出しているにすぎない。著者等は特にこの点に注意し て夷験したところ，相当多量のいーメチルテトラヒ்ドロフランの 生成していることを認めた。しかして，その生成量は反応温度を $260^{\circ} \mathrm{C}$ 以上にしたとき著しく增す。従つて 1,4 -ペンタンジオール を好収量で得るには反応温度を $240^{\circ} \mathrm{C}$ 程度にするのがよく, 又 初圧をなるべく大きくした方が収量のよいことが判つた。ところ でこの場合の 一ルから 2 次的に生成したすのと思われる。No. 8 の実験はこれ を確かめるために行つためのであつて，この反応条件に於ては 1,4-ペンタンジオールは還元反応と共に脱水反応をも受け易いこ とが明かになつた。

次にラ・ネーニッケルを触媒とした場合は既述の如く Adkins 等 の実験があるが,著者等は反応温度を高くすることにより $\boldsymbol{\alpha}$ 一メチ ルテトラヒドロフランの収量を増大せしめ, 又副生成物として nーバレリアン酸を確認した。アミルアルコール（n一か：－かは不 明）は生成量が少く n一バレリアン酸のエステルとして単離され, 又 1,4-ペンタンジオールの生成は認められなかつた。従つてこ の場合の主反底である
クトン環の CO 基の脱酸素によると考えられる。しかして n-ハ レリアン酸は $\gamma$-バレロラクトンのメチル基をるつ炭素原子と瞵 りの酸素原子との結合が加水素分解されて生じたすのであろう。

何れにしてす $\gamma$-バレロラクトンから直接 $\boldsymbol{\alpha ー メ チ ル テ ト ラ ヒ ト ゙ ~}$ ロフランを製造することは, その収量, 副反応の存在等からみて 経斉的でなく，前述の如くして 1,4-ペンタンジオールを作り， これから脱水 ${ }^{2}$ により 2 次的に製造する方がより実際的と思わ れる。

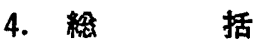

（1）レブリン酸の接触的水素添加による $\gamma$-バレロラクトン の製造について研究し，溶郕としてアルコールを使用することの 有利なことを認めた。

（2）この場合，アルカリ塩の水溶液としてラネーニッケル触 媒を用いて反応させると，低温です進行し，又触媒を合金のまま でも用い得ることを知つた。

（3） $\boldsymbol{\gamma}$-ハンレロラクトンを銅クロム酸化物触媒で水素添加する 場合, 反忘温度 $260^{\circ} \mathrm{C}$ 以上では相当多量の ロフランが得られ，これは 1,4-ペンタンジオールから脱水によ り 2 次的に生成したあのであることを明かにした。

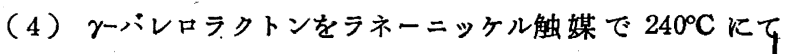
水素添加すると, 主生成物として が得られ，同時に n-ハンレリアン酸の副生が確認された。この場 合の主反応はラクトン環の $\mathrm{CO}$ 基の脱酸素と考えられる。

（5） $\gamma$-バレロラクトンから 1,4-ペンタンジオールを製造す るには銅クロム酸化物触媒を十分多量に用い,なるべく高圧にて, 温度 $240^{\circ} \mathrm{C}$ で水素添加するのがよい。 ランを製造するには，一旦 1,4 -ペンタンジオールを作り，これか ら脱水により得る力法が最も実際的であろう。

本研究に要した費用は文部省科学研究費及び味の素株式会社の 援助によつた。記して謝意を表する。

\section{（33） 魚津埋沒林による石炭化行程に関する研究（第 1 報）}

\section{埋沒樹杉材の組成について}

塚島寛・神田睦夫・大浦良一・笹岡治郎・沢江俊・福島亮吉

\section{I. 緒霄}

植物より石炭を生成する石炭化作用は岡氏1)によると，(イ)空 気中での生化学的蒣敗作用, (口) 水中での泥炭化作用, (八) 地 中での加压乾溜作用の 3 段階に分けられる。即ち植物がンシクテリ ア，好父性菌及支び嫌気性菌等による生化学的学敗作用により先ず 泥炭を生成し，これが地敬の変動等のため地下に埋没し地熱地圧 により順次覀炭, 褐炭, 暦青炭を得るのであるが，その石炭中の主 成分であるフミン貿はセルロース，リグニン何れを根源とするか

1) 風, 石炭 p. 46 (1944).
は永く論争された。それは F. Fischer ${ }^{2)}$ によるリグニン説, Bergius $^{3}$ ) 又は Wheeler(4)によるセルロース説, Marcusson ${ }^{5}$ に

2) F. Fischer, H. Schrader, Ges. Abhandl. Kenntnis Kohle 5, 543, 553, 559 (1920) ; Brenn. Chem. 3, 65, 341 (1922) ; F. Fischer, Ges. Abhandl. Kenntnis Kohle 6, 523 (1921).

3) F. Bergius, Naturwissenschaften 16, 1 (1928) ; P. Erasmus, Ueber die Bildung und den chemischen Bau der Kohlen (1938).

4) R. V. Wheeler, D. T. Jones, J. Chem. Soc. 109, 707 (1916). 